\title{
Rainwater propagation through snowpack during rain-on-snow sprinkling experiments under different snow conditions
}

\author{
Roman Juras $^{1,2}$, Sebastian Würzer ${ }^{2}$, Jirka Pavlásek ${ }^{1}$, Tomáš Vitvar ${ }^{1,3}$, and Tobias Jonas ${ }^{2}$ \\ ${ }^{1}$ Faculty of Environmental Sciences, Czech University of Life Sciences Prague, Kamýcká 129, \\ 165 21, Prague, Czech Republic \\ ${ }^{2}$ WSL Institute for Snow and Avalanche Research SLF, Flüelastrasse 11, 7260 Davos Dorf, Switzerland \\ ${ }^{3}$ Faculty of Civil Engineering, Czech Technical University in Prague, Thákurova 7, 16629 Prague 6, Czech Republic \\ Correspondence to: Roman Juras (juras@fzp.czu.cz)
}

Received: 20 November 2016 - Discussion started: 12 December 2016

Revised: 31 July 2017 - Accepted: 9 August 2017 - Published: 29 September 2017

\begin{abstract}
The mechanisms of rainwater propagation and runoff generation during rain-on-snow (ROS) events are still insufficiently known. Understanding storage and transport of liquid water in natural snowpacks is crucial, especially for forecasting of natural hazards such as floods and wet snow avalanches. In this study, propagation of rainwater through snow was investigated by sprinkling experiments with deuterium-enriched water and applying an alternative hydrograph separation technique on samples collected from the snowpack runoff. This allowed us to quantify the contribution of rainwater, snowmelt and initial liquid water released from the snowpack. Four field experiments were carried out during winter 2015 in the vicinity of Davos, Switzerland. Blocks of natural snow were isolated from the surrounding snowpack to inhibit lateral exchange of water and were exposed to artificial rainfall using deuterium-enriched water. The experiments were composed of four $30 \mathrm{~min}$ periods of sprinkling, separated by three $30 \mathrm{~min}$ breaks. The snowpack runoff was continuously gauged and sampled periodically for the deuterium signature. At the onset of each experiment antecedent liquid water was first pushed out by the sprinkling water. Hydrographs showed four pronounced peaks corresponding to the four sprinkling bursts. The contribution of rainwater to snowpack runoff consistently increased over the course of the experiment but never exceeded $86 \%$. An experiment conducted on a non-ripe snowpack suggested the development of preferential flow paths that allowed rainwater to efficiently propagate through the snowpack limiting the time for mass exchange processes to take effect. In contrast, experiments conducted on ripe isothermal
\end{abstract}

snowpack showed a slower response behaviour and resulted in a total runoff volume which consisted of less than $50 \%$ of the rain input.

\section{Introduction}

Rain-on-snow (ROS) events are a natural phenomenon which has been in the focus of hydrological research in the past decades, particularly because of their high potential to cause natural hazards. ROS events have initiated severe floods in the past in many European countries such as Germany (HND Bayern, 2011; Sui and Koehler, 2001), Switzerland (Badoux et al., 2013; Rössler et al., 2014) and the Czech Republic (Čekal et al., 2011), as well as in North America (Ferguson, 2000; Kattelmann, 1997; Marks et al., 1998; McCabe et al., 2007; Pomeroy et al., 2016). Rainwater also affects snowpack stability which can initiate formation of wet snow avalanches (Ambach and Howorka, 1966; Baggi and Schweizer, 2008; Conway and Raymond, 1993) or trigger slushflows (Hestnes and Sandersen, 1987; Nyberg, 1989; Onesti, 1987). In addition to natural hazards, ROS events are also relevant from a geochemical point of view. Rainwater affects the transport of ions (Jones et al., 1989) and solutes (Feng et al., 2001; Harrington and Bales, 1998; Lee et al., 2008; Waldner et al., 2004) through snow which affects the $\mathrm{pH}$ and chemical compositions of adjacent streams (Casson et al., 2014; Dozier et al., 1989; MacLean et al., 1995). 
The presence of liquid water in snow speeds up metamorphic processes such as snow settling, snowpack warming (Conway and Benedict, 1994) and grain coarsening (Gude and Scherer, 1998; Tusima, 1985). These processes entail a higher hydraulic conductivity and snow permeability which lead to faster water flow (Calonne et al., 2012; Conway and Benedict, 1994). Rainwater introduced to the snowpack during ROS represents an important additional source of liquid water besides snowmelt which can contribute to the generation of snowpack runoff.

Predicting snowpack runoff for an upcoming ROS event requires the understanding of water transport processes in snow. Water input from heavy rainfall typically flows faster through a snowpack than meltwater outside rain periods, which is why ROS situations may entail an augmented flood risk (Singh et al., 1998). Interactions between the liquid and solid phase of water make the water flow modelling in snow more difficult compared to other porous media like soil or sand where the solid phase is considered to be stable.

There is still a lack of knowledge regarding how rainwater propagates through a snowpack and, in particular, how this process is affected by various snowpack properties. Previous studies have shown that water transport in snow occurs in two different regimes, matrix flow and preferential flow, which are both governed by specific snow properties (Schneebeli, 1995; Waldner et al., 2004). In the matrix flow regime, snow is wetted top-down uniformly with all snow being wet above the wetting front (Schneebeli, 1995; Techel et al., 2008). Preferential flow, on the other hand, is characterized by spatially heterogeneous wetting patterns with horizontally isolated wet and dry zones often referred to as flow fingers (e.g. Techel et al., 2008; Waldner et al., 2004). The area involved in preferential flow has been shown to increase with inflow intensity and to decrease with grain size (Hirashima et al., 2014). During dye tracer experiments in a nonripe snowpack with temperatures below the freezing point, matrix flow was observed in the uppermost layers of the snowpack whereas preferential flow was observed in deeper layers only (Techel et al., 2008; Würzer et al., 2017). Various approaches of water flow transport in snowpack were further investigated which included rainfall simulation (Conway and Benedict, 1994; Eiriksson et al., 2013; Juras et al., 2013; Singh et al., 1997), artificial wetting (Avanzi et al., 2015; Katsushima et al., 2013; Yamaguchi et al., 2010) and numerical modelling (Hirashima et al., 2010, 2014; Wever et al., 2014a, 2015). Rainwater can refreeze when percolating through cold snow (Pfeffer and Humprey, 1998). An ice layer may form, e.g. when liquid water ponds on capillary barriers (Wever et al., 2016), and have a distinct impact on water transport (Eiriksson et al., 2013). Another aspect of water flow in subfreezing snow is that latent heat released by refreezing water can precondition the snowpack for subsequent runoff generation. Warming the snowpack changes both liquid-water content and the porous medium structure (Pfeffer et al., 1990).
Water transport was first quantitatively described by a gravity drainage water transport model for isothermal, homogeneous snow (Colbeck, 1972). Later, Illangasekare et al. (1990) introduced a 2-D model describing water transport in subfreezing and layered snow including capillary forces. With the implementation of the full Richard's equation (RE) described by Wever et al. (2014b), the influence of capillary forces on the water flow was finally represented in an operationally used 1-D SNOWPACK model. A multi-dimensional water transport model, which allows for the explicit simulation of preferential flow paths, has been introduced by $\mathrm{Hi}-$ rashima et al. (2014). Since multi-dimensional models are computationally intensive and lack the description of processes such as snow metamorphism and snow settling, they have not yet been shown to be suitable for hydrological or operational purposes. Recently, a new dual-domain approach of modelling water transport considering preferential flow was implemented in the 1-D SNOWPACK model (Wever et al., 2016; Würzer et al., 2017).

Due to the common different isotopic signature of rain and snow, hydrograph separation can be applied to differentiate rainwater from the meltwater in the total runoff from the snowpack. This is a widely used technique especially in watershed hydrology (Buttle et al., 1995; Dinçer et al., 1970; Unnikrishna et al., 2002). Snowpack usually features a heterogeneous vertical isotope composition (Lee et al., 2010; Zhou et al., 2008) which is partially homogenized over the course of the winter season by a combination of moisture exchange, meltwater presence and rain infiltration (Krouse et al., 1977; Unnikrishna et al., 2002). Isotopically lighter meltwater is produced at the beginning of snowmelt and becomes heavier as melt progresses. This change is augmented by isotopic enrichment of the meltwater through the late spring rainfalls (Unnikrishna et al., 2002). Several authors (Feng et al., 2002; Hashimoto et al., 2002; Unnikrishna et al., 2002) reported a typical difference of $\delta^{18} \mathrm{O}$ of approximately $2 \%$ o between solid snow and liquid water in snow which is mostly caused by the isotopic fractionation. Taylor et al. (2002) pointed out that a systematic error can occur if the isotopic signature of the snowpack is used instead of snowmelt for hydrograph separation purposes. Nevertheless, the study considered only daily time resolution when fractionation between ice and liquid water plays an important role. Studies estimating uncertainties of hydrograph separation within sub-hourly or hourly time resolution, which is typical for ROS events, are, to the best of the authors' knowledge, unavailable.

Juras et al. (2016) demonstrated in a feasibility study that they could quantify the contribution of rainwater in snowpack runoff during a sprinkling experiment using hydrograph separation techniques. However, their experiment was conducted with very high sprinkling intensities well beyond typical rain intensities. In this paper, we extend their study to investigate the propagation of liquid water through snowpack under conditions representative of natural ROS events and 
Table 1. Details of the experiments.

\begin{tabular}{lrrrlll}
\hline Site & Latitude & Longitude & Elevation & Label & Date & Meteo-observation during experiment \\
\hline Sertig 1 & $46.7227267^{\circ} \mathrm{N}$ & $9.8505897^{\circ} \mathrm{E}$ & $1850 \mathrm{~m}$ & Ex. 1 & 17-19 Mar 2015 & Light rain and snow, wind, partially cloudy/sunny \\
Sertig 2 & $46.7227856^{\circ} \mathrm{N}$ & $9.8507236^{\circ} \mathrm{E}$ & $1850 \mathrm{~m}$ & Ex. 2 & 22-24 Apr 2015 & Light wind, sunny \\
Dischma & $46.7209731^{\circ} \mathrm{N}$ & $9.9219625^{\circ} \mathrm{E}$ & $2000 \mathrm{~m}$ & Ex. 3 & 29 Apr-2 May 2015 & Wind and light rain, cloudy. \\
Flüela & $46.7436736^{\circ} \mathrm{N}$ & $9.9812761^{\circ} \mathrm{E}$ & $2150 \mathrm{~m}$ & Ex. 4 & 7-9 May 2015 & Sunny, very gentle wind \\
\hline
\end{tabular}

for different types of snowpack. Our data analysis answers the following questions:

1. How much does rainwater contribute to the total snowpack runoff during ROS?

2. Is there evidence of mass transfer processes between rainwater and ripe or non-ripe snow?

3. How do initial snowpack conditions of non-ripe and ripe snow influence liquid water transport in snow?

In addition, we present a new approach to deal with isotopic differences within the initial snowpack, and test it against standard procedures.

\section{Material and methods}

\subsection{Study site}

Four sprinkling experiments were carried out in the vicinity of Davos, Switzerland. The elevation of the experimental sites ranged between 1850 and $2150 \mathrm{~m}$ a.s.l. Details of all sites and experiments are summarized in Table 1. All sites were located in open flat terrain. The winter season 2014/2015 was characterized by lower snow cover depth and higher mean air temperature compared to the long-term averages. Davos climate has a subalpine character with mean air winter temperature of $-2.18^{\circ} \mathrm{C}$ and cumulative winter precipitation of $371 \mathrm{~mm}$ (November-April).

\subsection{Experimental procedure}

Four ROS experiments were conducted in this study. During each experiment, deuterium-enriched water was sprinkled on an isolated block of snow, consisting of natural and undisturbed snow of $1 \mathrm{~m}^{2}$ surface area. Each experiment was conducted within 3 consecutive days. On the first day, an experimental snow block of natural snow was prepared. To inhibit lateral exchange of water the snow block was carefully cut out and isolated from adjacent snow using four sheets of Ethafoam ${ }^{\circledR}$ of $2 \mathrm{~cm}$ thickness. A metal tray was pushed through the bottom section of the snow block at a slight angle enabling the collection of liquid water from the lowest corner. The tray featured a rim of $5 \mathrm{~cm}$ height on three of the four sides. The outlet channel was then attached to the fourth side, but only after the tray had been pushed through

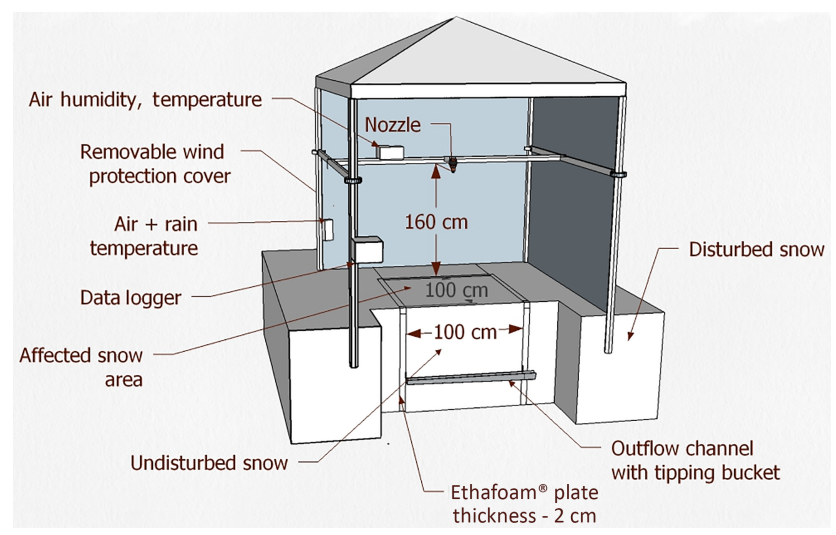

Figure 1. Experimental setup of rainfall simulator.

the snow block. The outlet was connected to a tipping bucket gauge, which also served to sample water for the laboratory analysis. The rainfall simulator was then placed above the snow block with a wind protection cover (Fig. 1) rolled up to ensure ambient thermal conditions.

On the second day, the actual sprinkling onto the snow block was performed. Pre-experimental snow properties were measured in undisturbed snow within a few metres of the experiment at the time that the sprinkling started. The authors recorded vertical profiles of snow temperature, liquid water content (LWC) and density. LWC was measured using a "Denoth meter" (Denoth, 1994). In addition, snow samples were taken to analyse the $\delta^{2} \mathrm{H}$ content. Snowpack runoff was recorded from $2 \mathrm{~h}$ before the first sprinkling burst until $5 \mathrm{~h}$ after the last sprinkling burst. The meltwater, preceding the sprinkling, was sampled to investigate how its mean isotopic signature differs from the isotopic signature of the entire snowpack. The snowpack runoff was further sampled for $\delta^{2} \mathrm{H}$ content during the entire experiment. The sampling interval varied according to the snowpack runoff rate, ranging from $1 \mathrm{~min}$ during the peak flow to $20 \mathrm{~min}$ during periods with marginal flow only. During the sprinkling, the wind protection cover was put in place to enable spatially homogeneous sprinkling results. The cover was briefly opened during the non-rain period to prevent the possible accumulation of warm air. On day 3 , approximately $20 \mathrm{~h}$ after the last sprinkling burst, post-experimental snow properties were measured analogously to day 2 , with the exception that the sampling was conducted within the snow block that had 
been sprinkled. Again, snow samples were taken to determine how much sprinkling water remained in the snowpack.

\subsection{Rainfall simulation and monitoring}

An enhanced version of the rainfall simulator described in Juras et al. $(2013,2016)$ was designed to achieve rain intensities close to observations during natural ROS events (Osterhuber, 1999; Rössler et al., 2014; Würzer et al., 2016). The new device was equipped by a Lechler 460.368.30.CA nozzle which was precisely calibrated in the laboratory and again on site. The nozzle was placed $160 \mathrm{~cm}$ above the snow cover ensuring a spatially uniform rainwater distribution for the inner $1 \mathrm{~m}^{2}$ of the sprinkling area, i.e. over the snow block.

Each of the four experiments consisted of four sprinkling periods lasting $30 \mathrm{~min}$, separated by a $30 \mathrm{~min}$ break. During each experiment, $41 \mathrm{~mm}$ of deuterium-enriched water was sprinkled on the isolated snowpack resulting in a mean rainfall intensity of $10.25 \mathrm{~mm} \mathrm{~h}^{-1}$ and $20.5 \mathrm{~mm} \mathrm{burst}^{-1}$, respectively. This approach was chosen to enable us to investigate the temporal progression of response times to signals in the sprinkling input as the snowpack conditions changed over the course of the experiment. The deuterium signature is expressed as a difference relative to the Vienna Standard Mean Ocean Water (V-SMOW). For the purposes of an efficient hydrograph separation, tap water was enriched with deuterium to reach a difference of at least $\delta^{2} \mathrm{H}=60 \%$ o V-SMOW between the snowpack and the sprinkling water. The sprinkling water deuterium signature ranged between $\delta^{2} \mathrm{H}-23.11$ and $+22.61 \%$ V-SMOW and the initial snowmelt deuterium signature ranged between $\delta^{2} \mathrm{H}-132.47$ and $-88.64 \%$ VSMOW. The barrels containing the enriched sprinkling water were buried into snow to cool the water temperature. The mean rainwater temperature after pumping varied between 4.3 and $7.5^{\circ} \mathrm{C}$ (measured over the snow), which is considered representative of temperatures during natural ROS events in the area.

\subsection{Sampling and laboratory analysis}

Water samples collected during the experiments were stored in 10 or $20 \mathrm{~mL}$ plastic bottles. To minimize isotopic fractionation, air gaps in the samples were avoided and samples were subsequently frozen until the laboratory analysis. Snow samples were taken along three vertical profiles at $10 \mathrm{~cm}$ spacing before and after each experiment. Additionally, three samples of the entire snow profile were taken at the same time. All snow samples were melted at room temperature, used to fill $10 \mathrm{~mL}$ plastic bottles and frozen until the laboratory analysis. The frozen samples were then melted in the laboratory prior to the analysis.

Analysis was carried out using a laser spectroscope of LGR Inc. at the LWIA v2 facility of the Czech Technical University in Prague (Penna et al., 2010). Samples and standards were measured in seven injections per vial. Samples were organized in sextets interlaced with three standards to bracket the isotopic content of all samples. This sequence was repeated three times. The standard deviation and $95 \%$ confidence intervals were based on 21 injections of each sample. The standard deviation between individual results of the same sample was $\delta^{2} \mathrm{H} 0.58 \%$ V-SMOW with a corresponding $95 \%$ confidence interval of $\delta^{2} \mathrm{H} 0.33 \%$ V-SMOW.

\subsection{Data analysis}

The hydrograph separation technique was used to separate rainwater from the non-rain water in the total runoff:

$$
\begin{aligned}
& Q_{\text {total }}(t) \cdot c_{\text {total }}(t)=Q_{\text {rain }}(t) \cdot c_{\text {rain }}+Q_{\text {non-rain }}(t) \\
& \quad \cdot c_{\text {non-rain }}(t), \\
& Q_{\text {total }}(t)=Q_{\text {rain }}(t)+Q_{\text {non-rain }}(t),
\end{aligned}
$$

where $Q\left(\mathrm{~mm} \mathrm{~min}^{-1}\right)$ is the flow rate, $c(\% \circ) \delta^{2} \mathrm{H}$ in $\mathrm{V}$ SMOW] is the deuterium signature and the subscripts total, rain and non-rain represent the total gauged snowpack runoff, the rainwater runoff and water originating from preexperimental LWC and snowmelt respectively.

The non-rain water was considered as a mixture of two components - pre-event liquid water content in the snowpack (pre-LWC) and the additional meltwater within the experimental snow block:

$Q_{\text {non-rain }}=Q_{\text {melt }}+Q_{\text {pre-LWC }}$.

Here $Q_{\text {melt }}$ represents additional meltwater produced during the experiment and $Q_{\text {pre-LWC }}$ represents pre-experimental liquid water content in the snowpack. Because the isotopic signature of the snowpack varies within the vertical profile, the authors assume that the reference value of non-rain water is not constant, but time variant. According to previous investigations (Juras et al., 2016), rainwater appears as snowpack runoff only after a certain delay. It can therefore be assumed that at the beginning of runoff the non-rain water consists mostly of pre-LWC ( $Q_{\text {pre-LWC }}$ ). After some time, the contribution of pre-LWC diminishes and additional meltwater ( $\left.Q_{\text {melt }}\right)$ begins to dominate within the non-rain runoff water volume. This water originating instantly from the solid phase has different isotopic signature compared to pre-LWC (Feng, 2002; Hashimoto et al., 2002; Unnikrishna et al., 2002). As a result, we introduce a new approach to non-rain water isotopic signature calculation. The partitioning of the non-rain water in the snowpack ( $c_{\text {non-rain }}$ in Eq. 1 ) can be expressed as

$$
\begin{aligned}
& c_{\text {non-rain }}=\tan ^{-1}\left(\frac{\frac{(T-t) \cdot 20 \pi}{S}}{\pi}+0.5\right) \cdot\left(c_{\text {snow }}-c_{\text {pre-melt }}\right) \\
& \quad+c_{\text {pre-melt }},
\end{aligned}
$$

where $T$ represents single time step $(\mathrm{min}), t(\mathrm{~min})$ is the time hypothetically needed to release all pre-LWC water, 
Table 2. Experimental snow block conditions before and after each experiment. Bulk density values were derived from the entire snow profile sample.

\begin{tabular}{|c|c|c|c|c|c|}
\hline \multirow[t]{2}{*}{ Snow properties } & \multicolumn{2}{|c|}{ Pre-experiment } & \multicolumn{2}{|c|}{ Post-experiment } & \multirow[t]{2}{*}{ Difference } \\
\hline & Mean & $\mathrm{SD}$ & Mean & $\mathrm{SD}$ & \\
\hline \multicolumn{6}{|c|}{ Ex. 1 - Sertig, snow pits 17-19 Mar 2015} \\
\hline Bulk density $\left(\mathrm{kg} \mathrm{m}^{-3}\right)$ & 247 & 4 & 251 & 8 & 4 \\
\hline Total LWC (\%) & 0.2 & 1.1 & 1.7 & 0.5 & 1.6 \\
\hline Total LWC (mm) & 0.9 & 0.3 & 8.3 & 2.4 & 7.4 \\
\hline Snow depth (cm) & 54.4 & 3.7 & 48.2 & 3.0 & -6.2 \\
\hline Snow temperature $\left({ }^{\circ} \mathrm{C}\right)$ & -1.0 & 0.6 & 0.0 & 0.0 & 1.0 \\
\hline \multicolumn{6}{|c|}{ Ex. 2 - Sertig, snow pits 22-24 Apr 2015} \\
\hline Bulk density $\left(\mathrm{kg} \mathrm{m}^{-3}\right)$ & 408 & 18 & 425 & 12 & 17 \\
\hline Total LWC $(\%)$ & 3.7 & 0.1 & 5.3 & 0.7 & 1.6 \\
\hline Total LWC (mm) & 11.0 & 0.3 & 13.9 & 1.1 & 2.8 \\
\hline Snow depth (cm) & 29.7 & 2.2 & 25.8 & 2.1 & -3.9 \\
\hline Snow temperature $\left({ }^{\circ} \mathrm{C}\right)$ & 0.0 & 0.0 & 0.0 & 0.0 & 0.0 \\
\hline \multicolumn{6}{|c|}{ Ex. 3 - Dischma, snow pits 29 Apr-1 May 2015} \\
\hline Bulk density $\left(\mathrm{kg} \mathrm{m}^{-3}\right)$ & 403 & 33 & 457 & 14 & 54 \\
\hline Total LWC (\%) & 3.8 & 0.3 & 6.3 & 0.1 & 2.6 \\
\hline Total LWC (mm) & 10.6 & 0.8 & 16.9 & 0.3 & 6.3 \\
\hline Snow depth (cm) & 28.1 & 2.5 & 26.6 & 2.1 & -1.6 \\
\hline Snow temperature $\left({ }^{\circ} \mathrm{C}\right)$ & 0.0 & 0.0 & 0.0 & 0.0 & 0.0 \\
\hline \multicolumn{6}{|c|}{ Ex. 4 - Flüela, snow pits 6-8 May 2015} \\
\hline Bulk density $\left(\mathrm{kg} \mathrm{m}^{-3}\right)$ & 477 & 21 & 495 & 9 & 18 \\
\hline Total LWC $(\%)$ & 3.5 & 0.5 & 5.6 & 0.3 & 2.1 \\
\hline Total LWC (mm) & 28.7 & 4.3 & 45.8 & 3.7 & 17.1 \\
\hline Snow depth $(\mathrm{cm})$ & 88.4 & 2.1 & 81.6 & 2.4 & -6.8 \\
\hline Snow temperature $\left({ }^{\circ} \mathrm{C}\right)$ & 0.0 & 0.0 & 0.0 & 0.0 & 0.0 \\
\hline
\end{tabular}

$S$ is a dimensionless parameter governing the shape of the curve, $c_{\text {snow }}$ is the mean deuterium signature of snow samples from the entire pre-experimental snowpack, and $c_{\text {pre-melt }}$ is the deuterium signature of pre-experimental meltwater. Parameter $t$ was derived as the time when the volume of non-rain water equalled pre-LWC (Fig. 2). The temporal smoothing parameter $S$ was set to a value of 45 and values of parameter $t$ were set individually for each experiment as follows: Ex. $1=20 \mathrm{~min}$, Ex. $2=95 \mathrm{~min}$, Ex. $3=88 \mathrm{~min}$, Ex. $4=215 \mathrm{~min}$. These values were chosen to best match the times estimated for the given pre-LWC volume to be released from the snowpack; see Sect. 4.4 for a discussion on the sensitivity of alternative approaches regarding Eq. (4). An illustration of the mixing curve is displayed in Fig. 2.

The isotopic value of the pre-LWC non-rain water was derived from the sampling of the pre-experiment melt outflow and the isotopic value of the additional melt was derived from the sample of the entire snowpack. The isotopic value of the rainwater was derived from the sampling of the water in the barrel. In view of the short duration of the experiment, the

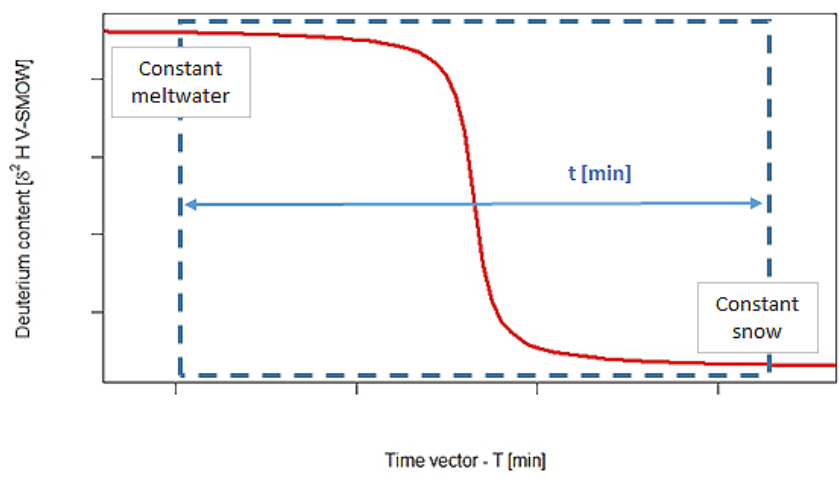

Figure 2. Generalized mixing curve of non-rain water $c_{\text {non-rain }}(t)$ representing a transition from the deuterium signature of preexperimental LWC to a value which is influenced by additional melt. 
Table 3. Overview of deuterium signature changes within each experiment. Reference values were used in Eqs. (1) and (4) for hydrograph separation. Snow samples were taken by extracting a vertical core from the entire snow profile.

\begin{tabular}{lrrrrr}
\hline & \multicolumn{2}{c}{ Pre-experimental reference value } & $\begin{array}{r}\text { Reference value } \\
\text { after experiment }\end{array}$ & Difference \\
\cline { 2 - 4 } & Rainwater & Meltwater & Snow sample & Snow sample & Snow sample \\
\hline Ex. 1 & -23.11 & -88.64 & -138.88 & -139.76 & -0.88 \\
Ex. 2 & -5.60 & -123.49 & -120.41 & -116.32 & 4.09 \\
Ex. 3 & 22.61 & -132.47 & -122.00 & -105.84 & 16.16 \\
Ex. 4 & -13.16 & -118.66 & -127.48 & -116.22 & 11.26 \\
\hline
\end{tabular}

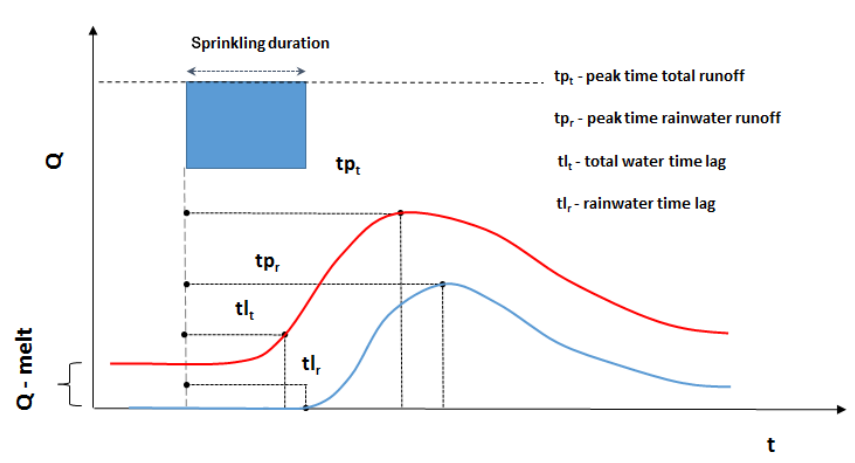

Figure 3. Graphical definition of peak times and time lags.

authors do not assume any fractionation between solid and liquid phase during the sprinkling.

Rainwater storage in the snow cube was estimated as

$Q_{\text {stored }}=Q_{\text {rain-in }}-Q_{\text {rain-out }}$.

The authors define the LWC deficit as the non-rain water contribution to the snowpack runoff that cannot be satisfied from the initial LWC storage. Hence, values above zero indicate the minimal snowmelt that must have occurred to provide LWC for the snowpack runoff. The LWC deficit is calculated as a cumulative deficit from the water balance as

$\operatorname{LWC}_{\text {deficit }}(t)=\max \left(\sum_{0}^{t} V_{\text {non-rain }}-\mathrm{LWC}_{\text {init }}, 0\right)$,

where $\mathrm{LWC}_{\text {init }}$ refers to initial total LWC summarized in Table 2 and $V_{\text {non-rain }}$ refers to the volume of non-rain water in the runoff. Hydrograph data were analysed for time lag and peak times of each hydrograph component (Table 4). We define rainwater time lag as the time when rainwater runoff rate reaches $0.01 \mathrm{~mm} \mathrm{~h}^{-1}$ (according to Eqs. 1, 2). Total water time lag is defined as the time difference between the onset of the rain and the first occurrence of snowpack runoff to exceed $150 \%$ of the initial meltwater flow (Fig. 3). Peak time is defined as the time difference between the onset of the rain and the time of runoff maximum of each hydrograph component.

Uncertainties in rainwater runoff contribution were estimated using the spread between individual samples from the vertical snow profiles at 10 and $90 \%$ percentiles. The isotopic signature of the pre-experimental snowpacks vertical samples from all experiments ranged between -166.64 and $-90 \%$.

\section{Results}

\subsection{Snowpack changes}

Table 2 shows an overview of the pre-experimental and postexperimental snowpack conditions. The three snow blocks in Ex. 2-4 consisted of snow with similar conditions which included characteristics such as isothermal, well ripened with bulk densities above $400 \mathrm{~kg} \mathrm{~m}^{-3}$ and containing considerable initial liquid water. These snowpack conditions are referred to in the text as "ripe snow". Pre-experimental snowpack conditions in Ex. 1 differed from the other three. Snow temperatures were mostly below the freezing point, ranging from 0 to $-1.8^{\circ} \mathrm{C}$. Only the top $5 \mathrm{~cm}$ featured snow temperatures of $0^{\circ} \mathrm{C}$, which was the only part of the snow profile where pre-experimental LWC was found. The bulk density of the snowpack in Ex. 1 was around $250 \mathrm{~kg} \mathrm{~m}^{-3}$. These snowpack conditions are further referred to as "non-ripe snow".

Ripe snowpacks resulted in greater density changes compared to the density changes in the non-ripe snowpack. The total bulk density increased by 17 to $54 \mathrm{~kg} \mathrm{~m}^{-3}$ in Ex. 2-4 compared to a $4 \mathrm{~kg} \mathrm{~m}^{-3}$ increase only in Ex. 1 (Table 2). In contrast, LWC increased in all experiments by very similar values of approx. $2 \%$.

An increased deuterium signature of snow, caused by the isotopically enriched sprinkling water, indicated additional storage of rainwater. The results showed a considerable increase in deuterium signature (Table 3) only for Ex. 2-4 (ripe snow conditions). In comparison, Ex. 1 (non-ripe snow) showed a more ambiguous picture, indicating that only little rainwater volume remained in the snow after the experiment; if anything, the deuterium signature even decreased slightly (by $-0.88 \%$ ). Details of the deuterium signature of the main components before and after the experiments are listed in Table 3 and Fig. 4, which also complete the deuterium signature development in the runoff. 

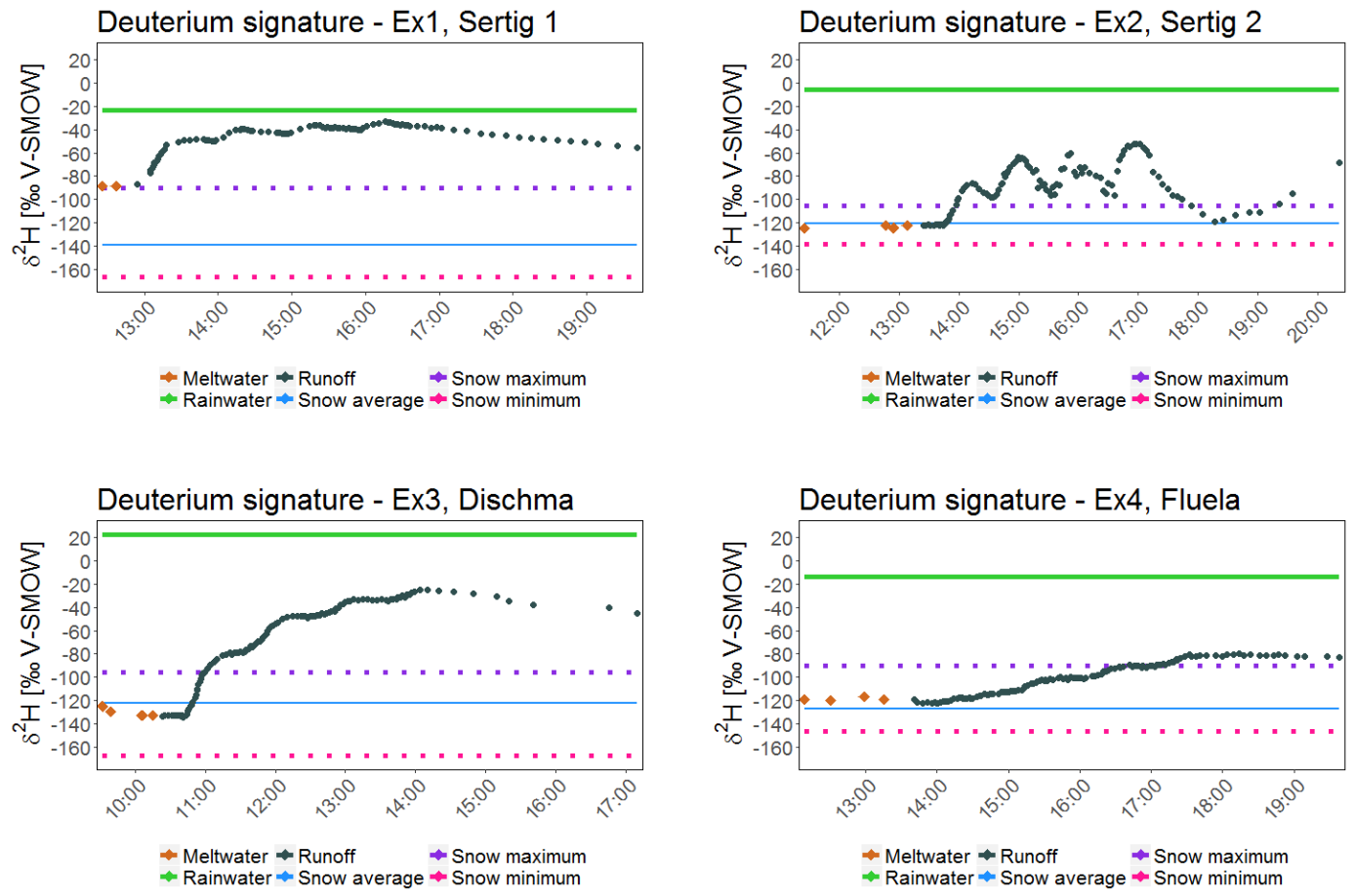

Figure 4. Deuterium signature of the snowpack runoff during sprinkling (blue dots) or pre-sprinkling meltwater (red dots). The lines represent the range (minimum and maximum) and averages of the deuterium signature derived for snow samples and the sprinkling water (rain).

\subsection{Snowpack runoff}

All experiments showed a quick response in snowpack runoff within $10 \mathrm{~min}$ (Ex. 1) to $27 \mathrm{~min}$ (Ex. 4) after the start of sprinkling (Fig. 5). However, the first significant increase of deuterium signature was detected in the runoff somewhat later. Time lags and peak flow times of the main hydrograph components are summarized in Table 4 . The difference between rainwater time lag and total water time lag indicates the delay of rainwater appearance in the snowpack runoff relative to other sources of LWC. Interestingly, this delay was considerable in Ex. 2-4 (at least $12 \mathrm{~min}$ ), but only minor (6 min) in Ex. 1, which was the only one conducted on non-ripe snow.

Additionally, the difference between total runoff and rain runoff demonstrates that water from other sources than rain such as pre-experimental LWC dominated snowpack runoff at the beginning of the sprinkling experiment. Again, it is Ex. 1 that deviates from the others by featuring a higher rain contribution in the total runoff already during the first sprinkling period (Fig. 5). Towards the end of the experiment (sprinkling period 4), rain contributed only $27 \%$ in Ex. 4 but $82 \%$ in Ex. 1.

The total water time lag was similar between the four sprinkling periods of each experiment, with the exception of Ex. 1 that featured a considerably longer time lag in the first sprinkling period compared to all subsequent periods, which may hint at the development of preferential flow paths early on during the experiment.
To test the sensitivity of our results to the parameters $S$ and $t$ used in Eq. (4) we recalculated rainwater time lags, rainwater peak times and cumulative rainwater using varying parameter values. We also used two sources of non-rain water (with different deuterium signature) (Table 5). While in general the differences between results from different approaches were small, notably different time lags resulted when using a constant isotopic value sampled from the entire snow column. Particularly in Ex. 1 when the isotopic value from the snowpack is used, the resulting rainwater time lag of $0 \mathrm{~min}$ seems unrealistic. This approach also resulted in reduced time lag by $48 \mathrm{~min}$ in Ex. 4, compared to the other approaches. It seems therefore important to consider a realistic isotopic value for meltwater, which does not necessarily equal the isotopic signature averaged over the entire snow profile.

\subsection{Water balance}

All experiments showed a negative snowpack mass balance (Table 6), which is characterized by cumulative total runoff (output) exceeding the cumulative rain input (Fig. 6). This required that additional melt occurred during all experiments. Cumulative event runoff computed according to Eqs. (1) and (2) consisted of between $22.0 \%$ (Ex. 4) and $76.4 \%$ (Ex. 1) of rainwater (Table 6, Fig. 6). The storage of rainwater was calculated according to Eq. (5) which revealed that, averaged over the entire experiment, the snowpack retained $21.6 \%$ 
Table 4. Hydrograph analysis of different artificial ROS events.

\begin{tabular}{|c|c|c|c|c|c|}
\hline $\begin{array}{l}\text { Sprinkling } \\
\text { period }\end{array}$ & $\begin{array}{r}\text { Time lag } \\
\text { total (min) }\end{array}$ & $\begin{array}{l}\text { Time lag } \\
\text { rain (min) }\end{array}$ & $\begin{array}{r}\text { Rainwater } \\
\text { velocity } \\
\left(\mathrm{cm} \mathrm{min}^{-1}\right)\end{array}$ & $\begin{array}{l}\text { Peak time } \\
\text { total (min) }\end{array}$ & $\begin{array}{l}\text { Peak time } \\
\text { rain (min) }\end{array}$ \\
\hline \multicolumn{6}{|c|}{ Ex. $1-$ Sertig 17-19 Mar $2015-$ snow depth $=54.4 \mathrm{~cm}$} \\
\hline 1 & 10 & 16 & 3.40 & 27 & 33 \\
\hline 2 & 4 & 4 & 13.60 & 22 & 27 \\
\hline 3 & 4 & 4 & 13.60 & 20 & 27 \\
\hline 4 & 5 & 5 & 10.88 & 25 & 25 \\
\hline \multicolumn{6}{|c|}{ Ex. 2 - Sertig 22-24 Apr $2015-$ snow depth $=29.7 \mathrm{~cm}$} \\
\hline 1 & 15 & 27 & 1.10 & 35 & 40 \\
\hline 2 & 13 & 13 & 2.28 & 31 & 36 \\
\hline 3 & 17 & 17 & 1.75 & 28 & 10 \\
\hline 4 & 13 & 14 & 2.12 & 30 & 10 \\
\hline \multicolumn{6}{|c|}{ Ex. 3 - Dischma 29 Apr-1 May $2015-$ snow depth $=29 \mathrm{~cm}$} \\
\hline 1 & 13 & 26 & 1.08 & 33 & 36 \\
\hline 2 & 9 & 9 & 3.12 & 29 & 34 \\
\hline 3 & 11 & 11 & 2.55 & 28 & 31 \\
\hline 4 & 9 & 9 & 3.12 & 27 & 27 \\
\hline \multicolumn{6}{|c|}{ Ex. $4-$ Flüela 6-8 May $2015-$ snow depth $=88.4 \mathrm{~cm}$} \\
\hline 1 & 27 & $\infty^{*}$ & $\mathrm{n} / \mathrm{a}^{*}$ & 50 & $\mathrm{n} / \mathrm{a}^{*}$ \\
\hline 2 & 27 & 27 & 3.27 & 47 & 49 \\
\hline 3 & 27 & 27 & 3.27 & 46 & 53 \\
\hline 4 & 32 & 32 & 2.76 & 47 & 51 \\
\hline
\end{tabular}

* Rainwater was not recorded in response to the first sprinkling burst; n/a: not applicable.

Table 5. Different methods for estimation of reference non-rain water isotopic value were used. 1: constant value of (a) entire snow sample, (b) pre-experimental meltwater. 2: different parameters $t$ and $S$ in Eq. (4), where (a) is parameter used from Table 2; (b) is modified parameter from Table $2 ; t=t / 2, S=S$; (c) is modified parameter from Table $2 ; t=2 t, S=S$; (d) is modified parameter from Table $2 ; t=t, S / 2=S$; (e) is modified parameter from Table $2 ; t=t, S=2 S$.

\begin{tabular}{|c|c|c|c|c|c|c|c|c|c|c|c|c|c|}
\hline \multicolumn{2}{|c|}{ Non-rain reference isotopic source } & \multicolumn{4}{|c|}{ Time lag rain (min) } & \multicolumn{4}{|c|}{ Peak time rain (min) } & \multicolumn{4}{|c|}{ Total rain output (min) } \\
\hline & & Ex. 1 & Ex. 2 & Ex. 3 & Ex. 4 & Ex. 1 & Ex. 2 & Ex. 3 & Ex. 4 & Ex. 1 & Ex. 2 & Ex. 3 & Ex. 4 \\
\hline \multirow[t]{2}{*}{1} & (a) Only snow & 0 & 29 & 31 & 39 & 30 & 42 & 38 & 62 & 34.2 & 18.2 & 21.6 & 16.2 \\
\hline & (b) Only melt & 16 & 27 & 26 & 87 & 33 & 40 & 36 & - & 28.1 & 19.1 & 23.2 & 12.7 \\
\hline \multirow[t]{5}{*}{2} & (a) Mixing - used & 16 & 27 & 26 & 87 & 33 & 40 & 36 & - & 32.6 & 18.8 & 22.8 & 12.8 \\
\hline & (b) Mixing $-t / 2$ & 15 & 27 & 26 & 87 & 29 & 40 & 36 & - & 33.8 & 18.5 & 22.3 & 13.8 \\
\hline & (c) Mixing $-2 t$ & 16 & 27 & 26 & 87 & 33 & 40 & 36 & - & 31.4 & 19.1 & 23.2 & 12.8 \\
\hline & (d) Mixing $-S / 2$ & 16 & 27 & 26 & 87 & 33 & 40 & 36 & - & 32.5 & 18.8 & 22.8 & 12.8 \\
\hline & (e) Mixing $-2 S$ & 15 & 27 & 26 & 87 & 33 & 40 & 36 & - & 32.6 & 18.8 & 22.8 & 12.8 \\
\hline
\end{tabular}

(Ex. 1) to $69.6 \%$ (Ex. 4) of the original rainwater volume. However, the rainwater storage ratio varied over the course of the experiment. After the first sprinkling period, the proportion was always highest and decreased with subsequent sprinkling periods (Table 6), and even diminished almost completely towards the end of Ex. 1.

The pre-LWC represented an important source of nonrain water in the snowpack runoff, especially during the first sprinkling period. The LWC deficit for each sprinkling period is shown in Table 6. For example, in Ex. 1 only $0.9 \mathrm{~mm}$ of pre-LWC was available (Table 2), but $4.1 \mathrm{~mm}$ of non-rain water appeared in the outflow after the first sprinkling period (Table 6), resulting in a LWC deficit of $3.17 \mathrm{~mm}$ that must have been satisfied by snowmelt. In contrast, the initial snowpack in Ex. 2-4 contained sufficient pre-LWC to fully explain the non-rain component to the runoff from the 

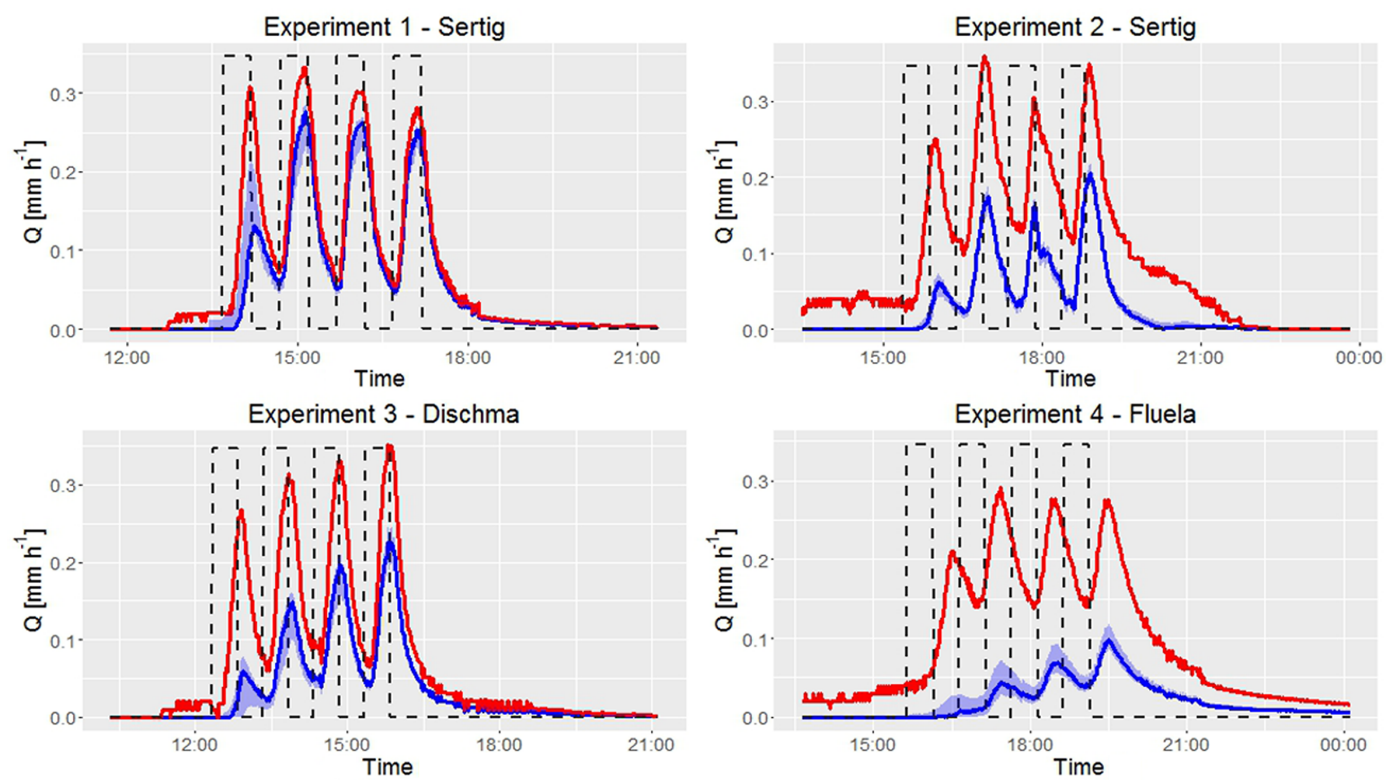

Figure 5. Runoff from the experimental snow block during all sprinkling experiments. $X$-axis is in resolution of minutes.

first sprinkling period. On the other hand, towards the end of these experiments, some snowpack runoff must occur due to meltwater.

\section{Discussion}

\subsection{Rainwater interaction with the snowpack}

All samples from snowpack runoff at the beginning of all sprinkling experiments revealed that the first water to extract from the snowpack originated from pre-LWC, and not from the rain. Only with a certain time lag did rain start to appear in the runoff samples. Obviously, rainwater introduced to the snowpack pushed existing pre-LWC water out of the snow block during the onset of the runoff generation. The first water samples taken from the runoff featured a similar deuterium signature as the pre-LWC water, leading to the assumption that pre-LWC predominated in the non-rain water at the beginning of the experiment, but as the pre-LWC storage depleted, meltwater superseded. The process whereby rainwater shifted the pre-LWC out of the snow matrix can be described as piston flow (Feng et al., 2001; Unnikrishna et al., 2002). The piston flow effect probably played a role not only at the beginning of runoff generation but also during the entire sprinkling experiment. Time shifts in peak flow times suggest that rainwater pushed non-rain water even beyond the initial phase, although the effect weakened over the course of the experiment (Table 4). A similar process was also described in Juras et al. (2016).
Comparing the volume of retained rainwater within the first sprinkling period with the amount of released non-rain water (Table 6) reveals that, in all experiments, the initial snowpack had a liquid water deficit. Available pore space in the snowpack was filled after the beginning of the sprinkling, which also resulted in relatively little rainwater runoff during the first sprinkling period. The rainwater contribution, however, increased during subsequent sprinkling periods, as available storage capacity for liquid water depleted and preLWC water was removed. During all experiments, the ratio of rainwater in the total snowpack runoff was well below $100 \%$ at all times (Fig. 5). This indicates that some rainwater is constantly retained in the snowpack (refrozen or as LWC) over the entire course of the sprinkling within both non-ripe and ripe snow.

Differences in the results from Ex. 1 relative to results from the other experiments demonstrated that the contribution of rainwater to the runoff is influenced by the initial snowpack conditions. Non-ripe snowpack containing low pre-LWC volume allowed a high contribution of rainwater to the runoff (Ex. 1). On the other hand, ripe snowpack with considerable pre-LWC volume showed a stronger indication of piston flow, which resulted in mostly non-rain water to appear in early snowpack runoff. Adding rain, pre-LWC and additional melt resulted in total cumulative runoff volumes exceeding the cumulative rain input by $27 \%$ on average for the experiment with ripe snow (Ex. 2-4). In contrast, runoff from the non-ripe snowpack exceeded rain input by only $3 \%$. 

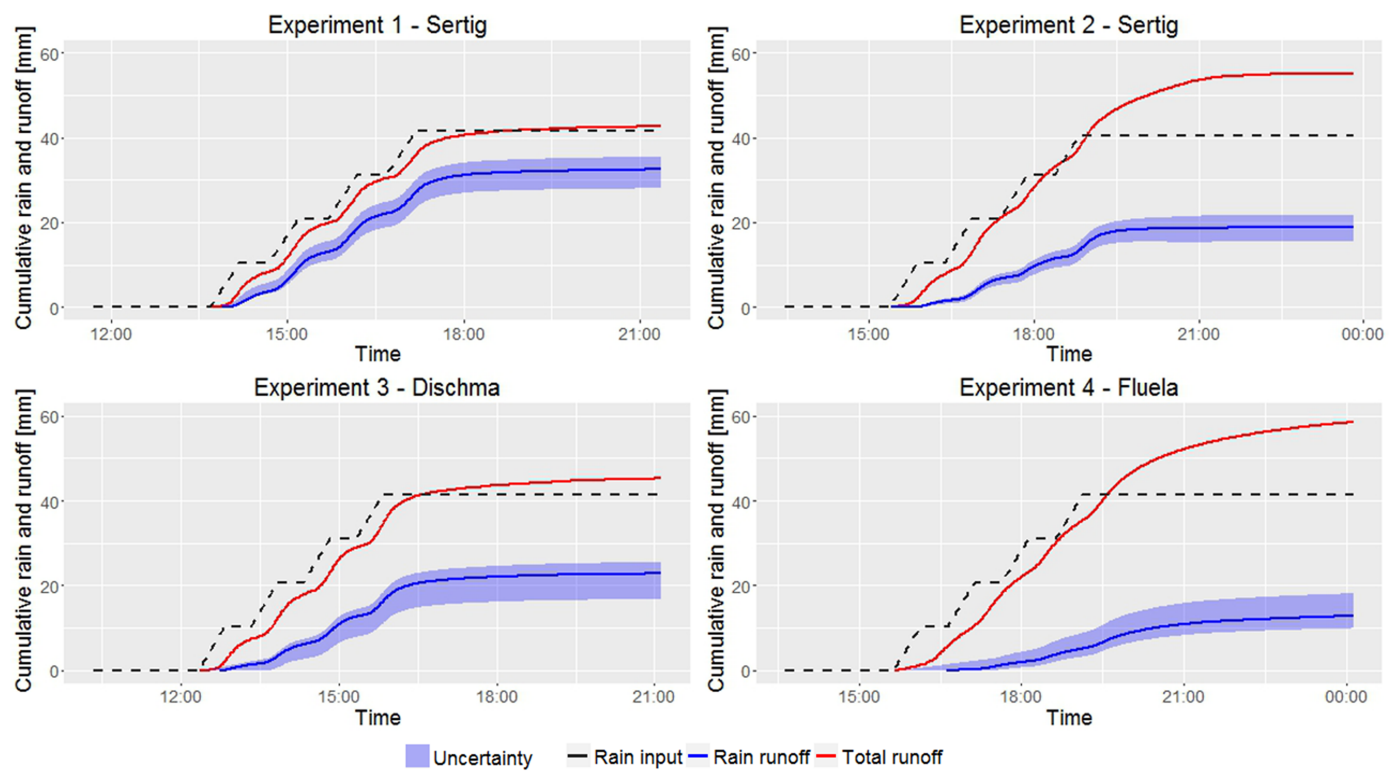

Figure 6. Cumulative runoff from the investigated snow cube. $X$-axis is in resolution of minutes.

\subsection{Rainwater transport within the snowpack}

The results showed that rainwater was transported much faster in non-ripe snow (Table 4), which indicated the presence of preferential flow (Sect. 3.2). The preferential flow paths probably developed rapidly after the rain onset due to microstructural transitions observed within the snow profile. This is supported by studies which investigated the formation of preferential flow (Hirashima et al., 2014; Katsushima et al., 2013; Techel et al., 2008). On the other hand, experiments with ripe snow resulted in a much slower transport of rainwater and showed evidence of the matrix flow regime. These findings are in agreement with previous studies, in which liquid water transport was monitored by dye tracer (Schneebeli, 1995; Würzer et al., 2017). The presence of capillary barriers supports water ponding and horizontal water movement (Avanzi et al., 2016), but also the generation of fast preferential flow paths (Eiriksson et al., 2013). During preferential flow, the wetting front is disaggregated into many smaller flow fingers, within which the hydraulic conductivity can be very high (Waldner et al., 2004), allowing water to be transported quickly. Given the experimental procedure, the preferential flow could not be observed visually. However, its presence was shown in supplementary sprinkling experiments using dye tracer on non-ripe snowpack similar to conditions during Ex. 1 (pre- $\mathrm{LWC}=0, T_{\text {snow }}=-1.6^{\circ} \mathrm{C}$ ) (Würzer et al., 2017). Also the presence of meltwater runoff at the onset of Ex. 1 suggests preferential flow, given that preLWC was only available in the top $5 \mathrm{~cm}$ of the snow profile.

The hydraulic conductivity is connected to the intrinsic permeability of snow, which increases as the snow density decreases (Calonne et al., 2012). The snow in Ex. 1 was characterized by a lower density and therefore supported the faster generation of snowpack runoff compared to Ex. 2Ex. 4. On the other hand, ripe snow typically features initial saturation which is associated with higher intrinsic permeability (Colbeck, 1972). In our experiments, however, the distinctly lower density of the snow in Ex. 1 in combination with the occurrence of preferential flows seem to have prevailed over other effects and caused a considerably faster transport of liquid water through the snowpack when compared to the experiments in ripe snow.

Ex. 1 aside, Ex. 2-4 showed similar initial snowpack conditions with the exception of snow depth (Table 2). This allowed us to verify that rainwater time lags were, as expected, sensitive to the transport distance. Time lags recorded during Ex. 4 were markedly longer than those recorded during Ex. 2-3, which supports a positive correlation between snow depth and water transport times as also noted by Wever et al. (2014a).

\subsection{Internal mass exchange}

Our results provide evidence of internal mass and energy exchange processes in the snowpack during the sprinkling experiments. Such processes represent refreezing of rainwater and generation of snowmelt (Avanzi et al., 2015; Wever et al., 2015), whereas mass has additionally been exchanged by the displacement of pre-LWC by rainwater.

After the first sprinkling period the non-ripe snowpack in Ex. 1 released more non-rain water than can be explained by available pre-experimental LWC. The corresponding LWC deficit even increases over the course of the sprinkling experiment (Table 6). This leads to the conclusion that snowmelt must have occurred as one of the processes involved in runoff generation. Further, the amount of rainwater retained in the 
Table 6. Water balance computed for every outflow peak of the four sprinkling experiments.

\begin{tabular}{|c|c|c|c|c|c|c|c|c|}
\hline $\begin{array}{l}\text { Sprinkling } \\
\text { period }\end{array}$ & $\begin{array}{l}\text { Input } \\
(\mathrm{mm})\end{array}$ & $\begin{array}{r}\text { LWC deficit } \\
(\mathrm{mm})\end{array}$ & $\begin{array}{r}\text { Total out } \\
(\mathrm{mm})\end{array}$ & $\begin{array}{r}\text { Rain out } \\
(\mathrm{mm})\end{array}$ & $\begin{array}{r}\text { Rain out } \\
(\%)\end{array}$ & $\begin{array}{l}\text { Non-rain } \\
\text { out }(\mathrm{mm})\end{array}$ & $\begin{array}{r}\text { Volume } \\
\text { rain stored } \\
(\mathrm{mm})\end{array}$ & $\begin{array}{r}\text { Volume } \\
\text { rain stored } \\
(\%)\end{array}$ \\
\hline \multicolumn{9}{|c|}{ Ex. 1 - Sertig 17-19 Mar 2015} \\
\hline 1 & 10.39 & 3.17 & 8.14 & 4.04 & 49.65 & 4.10 & 6.35 & 61.10 \\
\hline 2 & 10.39 & 5.36 & 11.48 & 9.29 & 80.95 & 2.19 & 1.10 & 10.56 \\
\hline 3 & 10.39 & 6.87 & 10.52 & 9.01 & 85.62 & 1.51 & 1.38 & 13.31 \\
\hline 4 & 10.39 & 9.15 & 12.53 & 10.26 & 81.85 & 2.27 & 0.13 & 1.29 \\
\hline Total & 41.56 & & 42.67 & 32.60 & 76.40 & 10.07 & 8.96 & 21.56 \\
\hline \multicolumn{9}{|c|}{ Ex. 2 - Sertig 22-24 Apr 2015} \\
\hline 1 & 10.13 & 0 & 8.98 & 1.76 & 19.63 & 7.22 & 8.37 & 82.60 \\
\hline 2 & 10.13 & 4.66 & 14.00 & 5.57 & 39.76 & 8.43 & 4.56 & 45.04 \\
\hline 3 & 10.13 & 11.55 & 11.49 & 4.60 & 40.04 & 6.89 & 5.53 & 54.59 \\
\hline 4 & 10.13 & 24.76 & 20.02 & 6.81 & 34.03 & 13.21 & 3.32 & 32.75 \\
\hline Total & 40.52 & & 54.49 & 18.74 & 34.40 & 35.75 & 21.78 & 53.74 \\
\hline \multicolumn{9}{|c|}{ Ex. 3 - Dischma 29 Apr-1 May 2015} \\
\hline 1 & 10.39 & 0 & 7.20 & 1.58 & 21.89 & 5.62 & 8.81 & 84.83 \\
\hline 2 & 10.39 & 0.25 & 10.44 & 5.14 & 49.21 & 5.30 & 5.25 & 50.55 \\
\hline 3 & 10.39 & 4.98 & 11.14 & 6.41 & 57.55 & 4.73 & 3.98 & 38.30 \\
\hline 4 & 10.39 & 11.55 & 16.22 & 9.64 & 59.46 & 6.58 & 0.75 & 7.17 \\
\hline Total & 41.56 & & 45.00 & 22.77 & 50.60 & 22.23 & 14.25 & 45.21 \\
\hline \multicolumn{9}{|c|}{ Ex. 4 - Flüela 6-8 May 2015} \\
\hline 1 & 10.39 & 0 & 4.62 & 0.00 & 0.00 & 4.62 & 10.39 & 100.00 \\
\hline 2 & 10.39 & 0 & 12.38 & 1.89 & 15.28 & 10.49 & 8.50 & 81.79 \\
\hline 3 & 10.39 & 0 & 12.08 & 3.16 & 26.14 & 8.92 & 7.23 & 69.61 \\
\hline 4 & 10.39 & 16.13 & 28.40 & 7.60 & 26.75 & 20.80 & 2.79 & 26.87 \\
\hline Total & 41.56 & & 57.48 & 12.65 & 22.00 & 44.83 & 28.91 & 69.57 \\
\hline
\end{tabular}

snowpack at the end of the experiment was larger than the final LWC which suggests that, at the same time, some rainwater has been refrozen or stored as liquid water. Nevertheless, these processes may have been limited to comparably small amounts of water since the LWC deficit, as well as the retained rainwater volume, was relatively small compared to the runoff volume. This conclusion is also supported by the small difference between the deuterium signature of the snowpack before and after the experiment (Table 3 ).

Ex. 4, by contrast, started with sufficient LWC to explain the runoff originating from non-rain water until sprinkling period 4, even without additional snowmelt. However, apparently pre-experimental LWC has dominated the runoff generated early on during the experiment (see discussion on piston flow regime, Sect. 4.1). The same applies to Ex. 2 and 3, for which snowmelt was evidenced from at least sprinkling period 2 onwards. In all three experiments, the deuterium signature differed considerably in snow samples collected before and after the experiment. This suggests that mass ex- change processes have had a larger turnover compared to Ex. 1. Of these three experiments, Ex. 2 showed the highest LWC deficit (Table 6). Consequently, the total runoff included a higher portion of meltwater, which had a notable impact on the deuterium signature of the total runoff, especially between the sprinkling bursts.

Runoff generation from the snowpack is a very important mechanism especially at the catchment scale. During rain, snow cover can either attenuate runoff formation by retaining rainwater in the snowpack or augment runoff formation with water from snowmelt (Würzer et al., 2016). The presence of snow can further lead to high antecedent soil moisture (Webb et al., 2015; Williams et al., 2015) and to the formation of basal ice layers (Bayard et al., 2005; Stähli et al., 2001), which can support rapid runoff formation processes like overland flow. Many of the mechanisms described in this work, although investigated at the point scale, also apply at the catchment scale. However, processes such as overland flow or lateral flow in snow further add to the complexity of 
runoff generation of entire catchments. The presented hydrograph separation technique is, however, transferable to larger scale, if the natural rain has a spatially constant isotopic signature (McDonnell et al., 1990).

\subsection{Partitioning of non-rain water}

The deuterium signature of pre-experimental meltwater and samples taken from the entire snowpack profile differed within all experiments (Table 3). This is caused when snowmelt is not produced over the entire snow profile (Ex. 1). Often, snowmelt prevails in the upper part of the snowpack (see Sect. 4.2). Accordingly, the deuterium signature of preexperimental melt in Ex. 1 was very close to values sampled from the top level of the snow profile.

It is expected that the pre-experimental melt (sourcing from pre-LWC) is continuously depleted and meltwater is also concurrently produced from the snowpack with a different isotopic signature. This is why the authors introduced an enhanced approach of hydrograph separation between rainwater and non-rain water by allowing the non-rain water isotopic reference value to be variable in time. This method was compared to the more traditional approach (see Juras et al., 2016) in which a constant isotopic value is used from either pre-experimental meltwater or sampled from the entire snowpack (Table 5). While differences between the approaches are minor, using a time-variant non-rainwater reference value seems to be a reasonable approach to arrive at more accurate estimations of rainwater time lags and outflow volumes.

Implementing the new approach seems valuable, especially when the isotopic signature of the pre-event liquid water and of the entire snowpack differ significantly (Taylor et al., 2002). The most notable benefit of our approach is seen in an increased accuracy of the mass balance estimates (i.e. when quantifying contributions of rainwater, melt and antecedent liquid water in the snowpack runoff). However, with respect to time lags, using only the meltwater isotopic signature as reported in Feng et al. $(2001,2002)$ leads to very similar results.

\section{Conclusion}

In this study we investigated liquid water transport behaviour through natural snow by means of sprinkling experiments. Using deuterium-enriched water enabled us to determinate the movement of rainwater and initial liquid water content. Furthermore, the approach provided evidence of rainwater storage and meltwater generation occurring together over the course of the sprinkling experiments.

Interestingly, a sprinkling experiment on a non-ripe snowpack resulted in markedly different water transport dynamics in comparison with experiments on melting snow. Snowpack runoff responded comparably quickly to the onset of sprinkling, and rainwater arrived in the runoff with a short delay only. The overall proportion of rainwater in the runoff was around $80 \%$, indicating that internal mass exchange processes played a minor role. Data from this experiment further suggested the development of preferential flow paths that allowed rainwater to propagate with increasing efficiency through the snowpack as the sprinkling continued.

On the other hand, experiments conducted on wet isothermal snowpack showed a different behaviour. Snowpack runoff was considerably delayed relative to the onset of the sprinkling, and consisted of initial liquid water content only. Rainwater appeared in the runoff only with further delay and in a relatively low proportion, where the overall contribution of rainwater in the runoff did not exceed $50 \%$. At the same time, the total runoff volume exceeded rain input plus initial liquid water content which requires that additional water from snowmelt contributed to the runoff. Both findings demonstrate that internal mass exchange processes and the type of snowpack substantially affect runoff generation during rain on a melting snowpack.

Data availability. All data is available on request.

Competing interests. The authors declare that they have no conflict of interest.

Acknowledgements. We would like to thank the scientific exchange program Sciex-NMS ${ }^{\text {ch }}$ (project code 14.105), the Swiss Federal Office for the Environment FOEN and Internal Grant Agency of the Faculty of Environmental Sciences, CULS Prague (project 20144254) and the Swiss National Foundation (Scopes) project "Snow resources and the early prediction of hydrological drought in mountainous streams" (SREPDROUGHT) IZ73ZO_152506/CZ for the funding of the project. Many thanks also go to Timea Mareková and Pascal Egli for tremendous help and assistance during the field work and Raelene Sheppard for linguistic correction. We also thank the SLF staff for technical support and Martin Šanda for isotope analysis.

Edited by: Markus Weiler

Reviewed by: Juraj Parajka, Jakob Garvelmann, and one anonymous referee

\section{References}

Ambach, W. and Howorka, F.: Avalanche activity amd free water content of snow at Oberlung (1980 m a.s.l., Spring 1962), in Symposium at Davos 1965 - Scientific Aspects of Snow and Ice Avalanches, Vol. 69, 65-72, International Assocciation of Scientific Hydrology Publication 69, Davos, 1966.

Avanzi, F., Yamaguchi, S., Hirashima, H., and De Michele, C.: Bulk volumetric liquid water content in a seasonal snowpack: Modeling its dynamics in different climatic conditions, Adv. Water Re- 
sour., 86, 1-13, https://doi.org/10.1016/j.advwatres.2015.09.021, 2015.

Avanzi, F., Hirashima, H., Yamaguchi, S., Katsushima, T., and De Michele, C.: Observations of capillary barriers and preferential flow in layered snow during cold laboratory experiments, The Cryosphere, 10, 2013-2026, https://doi.org/10.5194/tc-10-20132016, 2016.

Badoux, A., Hofer, M., and Jonas, T.: Hydrometeorologische Analyse des Hochwasserereignisses vom 10. Oktober 2011, available at: http://www.wsl.ch/fe/gebirgshydrologie/wildbaeche/ projekte/unwetter2011/Ereignisanalyse_Hochwasser_Oktober_ 2011.pdf, (last access: 22 September 2017), 2013.

Baggi, S. and Schweizer, J.: Characteristics of wet-snow avalanche activity: 20 years of observations from a high alpine valley (Dischma, Switzerland), Nat. Hazards, 50, 97-108, https://doi.org/10.1007/s11069-008-9322-7, 2008.

Bayard, D., Stähli, M., Parriaux, A., and Flühler, H.: The influence of seasonally frozen soil on the snowmelt runoff at two Alpine sites in southern Switzerland, J. Hydrol., 309, 66-84, https://doi.org/10.1016/j.jhydrol.2004.11.012, 2005.

Buttle, J. M., Vonk, A. M., and Taylor, C. H.: Applicability of isotopic hydrograph separation in a suburban basin during snowmelt, Hydrol. Process., 9, 197-211, https://doi.org/10.1002/hyp.3360090206, 1995.

Calonne, N., Geindreau, C., Flin, F., Morin, S., Lesaffre, B., Rolland du Roscoat, S., and Charrier, P.: 3-D image-based numerical computations of snow permeability: links to specific surface area, density, and microstructural anisotropy, The Cryosphere, 6, 939-951, https://doi.org/10.5194/tc-6-939-2012, 2012.

Casson, N. J., Eimers, M. C., and Watmough, S. A.: Sources of nitrate export during rain-on-snow events at forested catchments, Biogeochemistry, 120, 23-36, https://doi.org/10.1007/s10533013-9850-4, 2014.

Colbeck, S. C.: A Theory of Water Percolation in Snow, J. Glaciol., 11, 369-385, https://doi.org/10.1017/S0022143000022346, 1972.

Conway, H. and Benedict, R.: Infiltration of water into snow, Water Resour. Res., 30, 641-649, 1994.

Conway, H. and Raymond, C. F.: Snow stability during rain, J. Glaciol., 39, 635-642, 1993.

Čekal, R., Ryglewicz, M., Boříková, L., Suchá, M., Přibyl, J., and Kotek, R.: Zpráva o povodni v lednu 2011, available at: http://portal.chmi.cz/files/portal/docs/hydro/ohp/ povoden_01_2011.pdf (last access: 17 October 2014), 2011 (in Czech).

Denoth, A.: An electronic device for long-terlll snow wetness recording, Ann. Glaciol., 19, 104-106, 1994.

Dinçer, T., Payne, B. R., Florkowski, T., Martinec, J., and Tongiorgi, E.: Snowmelt runoff from measurements of tritium and oxygen-18, Water Resour. Res., 6, 110-124, https://doi.org/10.1029/WR006i001p00110, 1970.

Dozier, J., Melack, J. M., Elder, K., Kattelmann, R., Marks, D., and Williams, M.: Snow, snowmelt, rain, runoff, and chemistry in a Sierra Nevada watershed, Santa Barbara, final reportcontract A6147-32, Calif. Air Resour. Board, Sacramento, 1989.

Eiriksson, D., Whitson, M., Luce, C. H., Marshall, H. P., Bradford, J., Benner, S. G., Black, T., Hetrick, H., and McNamara, J. P.: An evaluation of the hydrologic relevance of lateral flow in snow at hillslope and catchment scales, Hydrol. Process., 27, 640-654, https://doi.org/10.1002/hyp.9666, 2013.

Feng, X.: Isotopic evolution of snowmelt 1. A physically based one-dimensional model, Water Resour. Res., 38, 1217, https://doi.org/10.1029/2001WR000814, 2002.

Feng, X., Kirchner, J. W., Renshaw, C. E., Osterhuber, R. S., Klaue, B., and Taylor, S.: A study of solute transport mechanisms using rare earth element tracers and artificial rainstorms on snow, Water Resour. Res., 37, 1425-1435, https://doi.org/10.1029/2000WR900376, 2001.

Feng, X., Taylor, S., Renshaw, C. E., and Kirchner, J. W.: Isotopic evolution of snowmelt 1 . A physically based onedimensional model, Water Resour. Res., 38, 35-1-35-8, https://doi.org/10.1029/2001WR000814, 2002.

Ferguson, S. A.: The spatial and temporal variability of rain-onsnow, in Assessment International Snow Science Workshop, 1-6 October 2000, 178-183, American Avalanche Association, Big Sky, Montana, 2000.

Gude, M. and Scherer, D.: Snowmelt and slushflows: hydrological and hazard implications, J. Glaciol., 26, 381-384, 1998.

Harrington, R. and Bales, R. C.: Modeling ionic solute transport in melting snow, Water Resour. Res., 34, 1727-1736, 1998.

Hashimoto, S., Shiqiao, Z., Nakawo, M., Sakai, A., Ageta, Y., Ishikawa, N., and Narita, H.: Isotope studies of inner snow layers in a temperate region, Hydrol. Process., 16, 2209-2220, https://doi.org/10.1002/hyp.1151, 2002.

Hestnes, E. and Sandersen, F.: Slushflow activity in the Rana district, North Norway, in: Avalanche Formation, Movement and Effect (Proceedings of Davos Symposium, September 1986), 317-330, IAHS Publ. 162, Davos, 1987.

Hirashima, H., Yamaguchi, S., Sato, A., and Lehning, M.: Numerical modeling of liquid water movement through layered snow based on new measurements of the water retention curve, Cold Reg. Sci. Technol., 64, 94-103, https://doi.org/10.1016/j.coldregions.2010.09.003, 2010.

Hirashima, H., Yamaguchi, S., and Katsushima, T.: A multidimensional water transport model to reproduce the preferential flow in a snowpack, Cold Reg. Sci. Technol., 108, 31-37, https://doi.org/10.1016/j.coldregions.2014.09.004, 2014.

HND Bayern: Gewässerkundlicher Monatsbericht Januar 2011 Hochwasser, available at: http://media.hnd.bayern.de/berichte/ md_fghw_0111.pdf (last access: 22 September 2017), 2011 (in German).

Illangasekare, T. H., Walter, R. J., Meier, M. F., and Pfeffer, W. T.: Modeling of meltwater infiltration in subfreezing snow, Water Resour. Res., 26, 1001-1012, https://doi.org/10.1029/WR026i005p01001, 1990.

Jones, H. G., Tranter, M., and Davies, T. D.: The leaching of strong acid anions from snow during rain-on-snow events: evidence for two component mixing, in Atmospheric Deposition, IAHS Publ., 239-250, available at: http://iahs.info/redbooks/a179/iahs_179_ 0239.pdf (last access: 22 September 2017), 1989.

Juras, R., Pavlásek, J., Děd, P., Tomášek, V., and Máca, P.: A portable simulator for investigating rain-on-snow events, Z. Geomorphol., 57, 73-89, https://doi.org/10.1127/0372-8854/2012/S00088, 2013.

Juras, R., Pavlásek, J., Vitvar, T., Šanda, M., Holub, J., Jankovec, J., and Linda M.: Isotopic tracing of the outflow dur- 
ing artificial rain-on-snow event, J. Hydrol., 1, 1145-1154, https://doi.org/10.1016/j.jhydrol.2016.08.018, 2016.

Katsushima, T., Yamaguchi, S., Kumakura, T., and Sato, A.: Experimental analysis of preferential flow in dry snowpack, Cold Reg. Sci. Technol., 85, 206-216, https://doi.org/10.1016/j.coldregions.2012.09.012, 2013.

Kattelmann, R.: Flooding from rain-on-snow events in the Sierra Nevada, in: Water-Caused Natural Disasters, their Abatement and Control (Proceedings of the Anaheim Conference, California, June 1996), 59-65, IAHS Publ. 239, Anaheim, California, 1997.

Krouse, R., Hislop, R., Brown, H. M., West, T., and Smith, J. L.: Climatic and spatial dependence of the retention of $\mathrm{D} / \mathrm{H}$ and 180/160 abundances in snow and ice of North America, in Isotopes and Impurities in Snow and Ice, Vol. 1, 242-247, 1977.

Lee, J., Feng, X., Posmentier, E. S., Faiia, A. M., Osterhuber, R., and Kirchner, J. W.: Modeling of solute transport in snow using conservative tracers and artificial rain-on-snow experiments, Water Resour. Res., 44, 1-12, https://doi.org/10.1029/2006WR005477, 2008.

Lee, J., Feng, X., Faiia, A. M., Posmentier, E. S., Kirchner, J. W., Osterhuber, R., and Taylor, S.: Isotopic evolution of a seasonal snowcover and its melt by isotopic exchange between liquid water and ice, Chem. Geol., 270, 126-134, https://doi.org/10.1016/j.chemgeo.2009.11.011, 2010.

MacLean, R. A., English, M. C., and Schiff, S. L.: Hydrological and hydrochemical response of a small Canadian Shield catchment to late winter rain-on-snow events, Hydrol. Process., 9, 845-863, https://doi.org/10.1002/hyp.3360090803, 1995.

Marks, D., Kimball, J., Tingey, D., and Link, T.: The sensitivity of snowmelt processes to climate conditions and forest cover during rain-on-snow: a case study of the 1996 Pacific Northwest flood, Hydrol. Process., 12, 1569-1587, 1998.

McCabe, G. J., Hay, L. E., and Clark, M. P.: Rain-on-Snow Events in the Western United States, B. Am. Meteorol. Soc., 88, 319328, https://doi.org/10.1175/BAMS-88-3-319, 2007.

McDonnell, J. J., Bonell, M., Stewart, M. K., and Pearce, A. J.: Deuterium variations in storm rainfall: implications for stream hydrograph separation, Water Resour. Res., 26, 455-458, 1990.

Nyberg, R.: Observations of slushflows and their geomorphological effects in the Swedish mountain area, Geogr. Ann. A., 71, 185198, 1989

Onesti, L. J.: Slushflow release mechanism?: A first approximation, in Avalanche Formation, Movement and Effect, 331-336, IAHS Publ. 162, Davos, 1987.

Osterhuber, R. S.: Precipitation intensity during rain-on-snow, in Western Snow Conference, pp. 153-155, South Lake Tahoe, available at: http://www.westernsnowconference.org/sites/ westernsnowconference.org/PDFs/1999Osterhuber.pdf (last access: 9 December 2014), 1999.

Penna, D., Stenni, B., Šanda, M., Wrede, S., Bogaard, T. A., Gobbi, A., Borga, M., Fischer, B. M. C., Bonazza, M. and Chárová, Z:: On the reproducibility and repeatability of laser absorption spectroscopy measurements for $\delta^{2} \mathrm{H}$ and $\delta^{18} \mathrm{O}$ isotopic analysis, Hydrol. Earth Syst. Sci., 14, 1551-1566, https://doi.org/10.5194/hess-14-1551-2010, 2010.

Pfeffer, W. T. and Humprey, N. F.: Formation of ice layers by infiltration and refreezing of meltwater, Ann. Glaciol., 26, 83-91, 1998.
Pfeffer, T. W., Illangasekare, T. H., and Meier, M. F.: Analysis and modelling of melt-water refreezing in dry snow, J. Glaciol., 36, 238-246, 1990.

Pomeroy, J., Fang, X., and Marks, D. G.: The cold rain-onsnow event of June 2013 in the Canadian Rockies - characteristics and diagnosis, Hydrol. Process., 30, 2899-2914, https://doi.org/10.1002/hyp.10905, 2016.

Rössler, O., Froidevaux, P., Börst, U., Rickli, R., Martius, O., and Weingartner, R.: Retrospective analysis of a nonforecasted rainon-snow flood in the Alps - a matter of model limitations or unpredictable nature?, Hydrol. Earth Syst. Sci., 18, 2265-2285, https://doi.org/10.5194/hess-18-2265-2014, 2014.

Schneebeli, M.: Development and stability of preferential flow paths in a layered snowpack, IAHS-AIHS Publ., 228, 89-95, available at: http://www.iahs.info/uploads/dms/iahs_228_0089. pdf, 1995.

Singh, P., Spitzbart, G., Hübl, H., and Weinmeister, H. W.: The role of snowpack in producing floods under heavy rainfall, in Hydrology, Water Resources and Ecology in Headwaters, 89-95, IAHS Publ. 248, Merano, 1998.

Singh, V. P., Spitzbart, G., Hübl, H., and Weinmeister, H. W.: Hydrological response of snowpack under rain-on-snow events: a field study, J. Hydrol., 202, 1-20, https://doi.org/10.1016/S00221694(97)00004-8, 1997.

Stähli, M., Nyberg, L., Mellander, P.-E., Jansson, P.-E., and Bishop, K. H.: Soil frost effects on soil water and runoff dynamics along a boreal transect: 2. Simulations, Hydrol. Process., 15, 927-941, https://doi.org/10.1002/hyp.232, 2001.

Sui, J. and Koehler, G.: Rain-on-snow induced flood events in Southern Germany, J. Hydrol., 252, 205-220, https://doi.org/10.1016/S0022-1694(01)00460-7, 2001.

Taylor, S., Feng, X., Williams, M., and McNamara, J.: How isotopic fractionation of snowmelt affects hydrograph separation, Hydrol. Process., 16, 3683-3690, https://doi.org/10.1002/hyp.1232, 2002.

Techel, F., Pielmeier, C., and Schneebeli, M.: The first wetting of snow: micro-structural hardness measurements using a snow micro penetrometer, in International Snow Science Workshop, Vol. 1, 1019-1026, Whistler, 2008.

Tusima, K.: Grain coarsening of snow particles immersed in water and solution, Ann. Glaciol., 6, 126-129, 1985.

Unnikrishna, P. V., McDonnell, J. J., and Kendall, C.: Isotope variations in a Sierra Nevada snowpack and their relation to meltwater, J. Hydrol., 260, 38-57, https://doi.org/10.1016/S00221694(01)00596-0, 2002.

Waldner, P. A., Schneebeli, M., Schultze-Zimmermann, U., and Flühler, H.: Effect of snow structure on water flow and solute transport, Hydrol. Process., 18, 1271-1290, https://doi.org/10.1002/hyp.1401, 2004.

Webb, R. W., Fassnacht, S. R., and Gooseff, M. N.: Wetting and Drying Variability of the Shallow Subsurface Beneath a Snowpack in California's Southern Sierra Nevada, Vadose Zo. J., 14, https://doi.org/10.2136/vzj2014.12.0182, 2015.

Wever, N., Jonas, T., Fierz, C., and Lehning, M.: Model simulations of the modulating effect of the snow cover in a rain-on-snow event, Hydrol. Earth Syst. Sci., 18, 4657-4669, https://doi.org/10.5194/hess-18-4657-2014, 2014a.

Wever, N., Fierz, C., Mitterer, C., Hirashima, H., and Lehning, M.: Solving Richards Equation for snow improves snowpack melt- 
water runoff estimations in detailed multi-layer snowpack model, The Cryosphere, 8, 257-274, https://doi.org/10.5194/tc-8-2572014, 2014b.

Wever, N., Schmid, L., Heilig, A., Eisen, O., Fierz, C., and Lehning, M.: Verification of the multi-layer SNOWPACK model with different water transport schemes, The Cryosphere, 9, 2271-2293, https://doi.org/10.5194/tc-9-2271-2015, 2015.

Wever, N., Würzer, S., Fierz, C., and Lehning, M.: Simulating ice layer formation under the presence of preferential flow in layered snowpacks, The Cryosphere, 10, 2731-2744, https://doi.org/10.5194/tc-10-2731-2016, 2016.

Williams, M. W., Hood, E., Molotch, N. P., Caine, N., Cowie, R., and Liu, F.: The "teflon basin" myth: hydrology and hydrochemistry of a seasonally snowcovered catchment, Plant Ecol. Divers., 8, 639-661, https://doi.org/10.1080/17550874.2015.1123318, 2015.
Würzer, S., Jonas, T., Wever, N., and Lehning, M.: Influence of Initial Snowpack Properties on Runoff Formation during Rain-on-Snow Events, J. Hydrometeorol., 17, 1801-1815, https://doi.org/10.1175/JHM-D-15-0181.1, 2016.

Würzer, S., Wever, N., Juras, R., Lehning, M., and Jonas, T.: Modelling liquid water transport in snow under rain-on-snow conditions - considering preferential flow, Hydrol. Earth Syst. Sci., 21, 1741-1756, https://doi.org/10.5194/hess-21-1741-2017, 2017.

Yamaguchi, S., Katsushima, T., Sato, A., and $\mathrm{Ku}-$ makura, T.: Water retention curve of snow with different grain sizes, Cold Reg. Sci. Technol., 64, 87-93, https://doi.org/10.1016/j.coldregions.2010.05.008, 2010.

Zhou, S., Nakawo, M., Hashimoto, S., and Sakai, A.: The effect of refreezing on the isotopic composition of melting snowpack, Hydrol. Process., 22, 873-882, https://doi.org/10.1002/hyp, 2008. 